Chapter 26

\title{
The Effect of Industrial Heavy Metal Pollution on Microbial Abundance and Diversity in Soils - A Review
}

\author{
Anna Lenart-Boroń and Piotr Boroń \\ Additional information is available at the end of the chapter \\ http://dx.doi.org/10.5772/57406
}

\section{Introduction}

Metals are essential components of the ecosystem, whose biologically available concentrations depend mainly on geological and biological processes [1]. There are several definitions of heavy metals, and some of them are based on the mass density of these elements. Authors of numerous publications use different limits to define the threshold density for a "heavy metal",

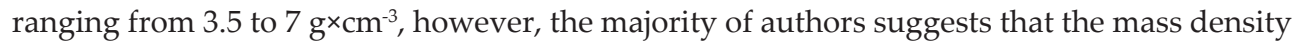
of heavy metals should be greater than $4.5 \mathrm{~g} \times \mathrm{cm}^{-3}$ [2]. Within the group of heavy metals one can distinguish both elements that are essential for living organisms (microelements) and the elements whose physiological role is unknown and thus they are "inactive" towards organisms. The metals that serve as microelements in living organisms usually occur in trace amounts, precisely defined for each species and both their deficiency and excess badly affect living organisms [3]. The term "heavy metal" is linked in many people's minds to metals that are toxic. However, this is not always the truth. The effect of any substance on a living system is always dependent on its available concentration to cells. Also, several heavy metal ions are crucial in metabolic processes at low concentrations but are toxic at high concentrations [2]. Nevertheless, locally elevated levels of these elements can create significant environmental and health problems when the release of metals through various biological, geological and anthropogenic processes far exceeds its natural content resulting from processes of metal cycling. Heavy metal pollution of terrestrial environments is of great concern, due to the persistence of metals in the ecosystem and their threat to all living organisms [4].

Given the importance of the subject of soil heavy metal pollution and its effect on soil microorganisms, this chapter gives an overview of the severity of the problem when it comes to the reaction of soil microbial community to the environmental pollution. The first part of this chapter deals with the abundance of microorganisms in soils and their role in this environment. 
The next part concerns major sources of heavy metals in soils with particular emphasis on the most important source of soil pollution, i.e. human activity (and more precisely - industry and mining). The following part discusses the effects that toxic levels of heavy metals may have on the microbial population in soils. The last two parts of this chapter describe the ways of dealing with heavy metal pollution - one introduces the term of phytoremediation (soil remediation with the use of plants) and the other one focuses on the use of microorganisms resistant to heavy metals in the process of soil remediation.

\section{The complexity of microbial community in soils}

Except for occasional insects or earthworms, once visible traces of plant biomass are removed, soil appears as a lifeless mass, that is composed of mineral particles and organic residues. However, even desert soils are abundant source of living microorganisms. This seemingly lifeless matter contains complex microbial community, including bacteria, fungi, protozoa and viruses. The integrity of the aboveground and belowground ecosystems depends on the stability, resilience and function of the soil microbial community [5].

Soil is an interesting medium for growing microorganisms, as it contains various nutrients that the microbes need for their metabolism. Unfortunately, nutrients are not always readily available [6]. However, it is one of the richest reservoirs of microorganisms, i.e. 1 gram of agricultural soil may contain even several billion colony forming units (CFUs) of microorganisms belonging to thousands of different species [7], and even though microorganisms constitute less than $0.5 \%$ of the soil mass, they have a major impact on soil properties and processes [5]. Table 1 presents the average numbers of soil microorganisms in a "typical" temperate soil. Destruction of the soil microbiota through mismanagement or environmental pollution causes decline or even death of the aboveground plant and animal populations.

\begin{tabular}{lccc}
\hline \multirow{2}{*}{ Organisms } & \multicolumn{2}{c}{ Numbers } & Biomass [wet kg $\times$ ha $^{-1}$ ] \\
\cline { 2 - 4 } & Per $\mathbf{m} \mathbf{2}$ & Per $\mathbf{g}$ & $300-3000$ \\
\hline Bacteria & $10^{13}-10^{14}$ & $10^{8}-10^{9}$ & $300-3000$ \\
\hline Actinomycetes & $10^{12}-10^{13}$ & $10^{7}-10^{8}$ & $500-5000$ \\
\hline Fungi & $10^{10}-10^{11}$ & $10^{5}-10^{6}$ & $10-1500$ \\
\hline Microalgae & $10^{9}-10^{10}$ & $10^{3}-10^{6}$ & \\
\hline
\end{tabular}

Table 1. Relative numbers and approximate biomass of the soil microbiota in a fertile soil [8].

The most characteristic feature of microbial habitats is the great micro-spatial variability of environmental parameters, like temperature or nutrient availability. Many basic requirements of heterogeneous microorganisms are satisfied by various soil microhabitats. This is the reason why, in ecological terms, a number of varying microbial niches can be described. Therefore, the microbial community is composed of diverse taxa with different nutritional demands 
within small microenvironments [9]. Analysis of the spatial distribution of bacteria at microhabitat levels showed that in soils subjected to different fertilization treatments, the majority of bacteria were located in micropores of stable soil micro-aggregates $(2-20 \mu \mathrm{m})$, as they contained over $80 \%$ of cells [10]. Such microhabitats offer the most favorable conditions for microbial growth in terms of water and substrate availability, gas diffusion and protection against predation. The microhabitat-adapted groups of microorganisms form so-called consortia which are held together by mutually facilitating metabolic processes. The consortia are characterized by more or less sharp boundaries, and variable level of interaction with each other and with other parts of the soil biota. Numerous investigations emphasize the impact of soil structure and spatial isolation on microbial diversity and community structure [11]. Some studies indicate that the soil particle size affects the diversity of microorganisms and community structure to a greater extent than other factors such as bulk $\mathrm{pH}$ and the type or amount of available organic compounds [12]. Other investigations show that the type and amount of available organic substrates strongly affect the abundance of microbial groups and their functional diversity in soils [13]. Fierer and Jackson [14] claim that the structure of soil bacterial communities is not random also at continental scale and that the diversity and composition of soil bacterial communities at large spatial scales can be predicted to a large extent by a single variable, that is soil $\mathrm{pH}$. The diversity of soil microorganisms comprises different levels of biological organization. It includes genetic variability among taxa (species), number (richness), relative abundance (evenness) of taxa and functional groups within communities [11]. The overall biodiversity of soil microflora comprises bacteria, fungi, actinomycetes and photosynthetic microorganisms [6].

Bacteria constitute the most numerous group of soil microbes - a teaspoon of productive soil contains between 100 million and 1 billion bacterial cells. As soil environment changes rather drastically, spore-forming bacteria tend to be the most common. When environmental conditions become too difficult for normal growth, the bacteria form spores and remain dormant until the environment returns to proper conditions [6]. They facilitate various processes in soils, e.g. those related to water dynamics, nutrient cycling or disease suppression [15]. Soil-dwelling bacteria may be divided into different groups based on:

- Shapes: rods (also called bacilli), sphere (also called cocci) and spiral (also called spirilla)

- Their reaction to oxygen: aerobic (bacteria that need oxygen for their survival) and anaerobic (the ones that do not require oxygen and in most cases cannot bear oxygen that is deadly for them)

- Result of Gram staining: Gram negative (stain pink and have thinner cell walls, they are the smallest ones and tend to be more sensitive to water stress) or Gram positive (stain violet, have thicker cell walls, are larger in size and tend to resist water stress)

- Source of carbon they use: autotrophs (obtain carbon from carbon dioxide - some autotrophic bacteria directly use sunlight in order to produce sugar from carbon dioxide, while others depend on various chemical reactions) or heterotrophs (they obtain carbohydrates from their environment) 
- Classification based on phyla: based on morphology, barcode DNA sequences, physiological requirements and biochemical characteristics, bacteria have been classified into 12 phyla. Each phylum corresponds to a number of bacterial species and genera [15].

Tate [5] lists the most commonly encountered soil bacterial genera as: Acinetobacter, Agrobacterium, Alcaligenes, Arthrobacter, Bacillus, Brevibacterium, Caulobacter, Cellulomonas, Clostridium, Corynebacterium, Flavobacterium, Hyphomicrobium, Metallogenium, Micrococcus, Mycobacterium, Pseudomonas, Sarcina, Streptococcus and Xanthomonas. These are the heterotrophic bacteria that are augmented in soil by autotrophic and mixotrophic representatives, including nitrifiers, Thiobacillus species and iron bacteria.

Bacteria facilitate a number of physical and biochemical alterations or reactions in soils and thereby directly or indirectly support the development of higher plants. Their performance is vital for a variety of processes that include: decomposition of cellulose or other carbohydrates (e.g. Bacillus, Achromobacter, Cellulomonas, Clostridium, Methanococcus), ammonification (Bacillus, Pseudomonas), nitrification (Nitrosomonas, Nitrobacter), denitrification (Achromobacter, Pseudomonas, Bacillus, Micrococcus) and nitrogen fixation (symbiotic Rhizobium, Bradyrhizobium etc., non-symbiotic Azotobacter, Beijerinckia) [16].

On the other hand, soil fungi form three functional groups: decomposers, mutualists and pathogens. Fungi, along with bacteria, are important decomposers of hard to digest organic matter and they increase nutrient uptake of phosphorus. Mycorrhizal fungi support plants by promoting root branching and increasing nitrogen, phosphorus and water uptake. They improve plant resilience to pests, diseases or drought and improve soil structure, as fungal hyphae binds soil particles together to create water-stable aggregates. They in turn create the pore spaces in the soil that enhance water retention and drainage [17]. The most common fungi found in soil belong to the Penicillium and Aspergillus genera together with the representatives of the Zygomycetes and the mycorrhizae-associated Ascomycetes and Basidiomycetes [5].

Actinomycetes are a large group of microorganisms, systematically identified as bacteria, that grow as hyphae. They decompose a wide range of substances, but they are particularly important in degrading recalcitrant (difficult to degrade) compounds such as chitin, lignin, keratin and cellulose. Moreover, they produce a number of secondary metabolites such as antibiotics i.e. streptomycin [18] or geosmine which is responsible for "earthy" smell after soil plowing [15]. Actinomycetes are important in forming stable humus, which enhances soil structure, improves soil nutrient storage and increases water retention in soils. According to Tate [5], the most commonly encountered soil actinomycetes belong to Nocardia and Streptomyces genera.

Algae are the most common among photosynthetic microorganisms found in soil. They are found only near soil surface, where light is readily available [6]. The most common genera of green algae found in soil are: Chlorella, Chlamydomonas, Chlorococcum, Protosiphon etc. and that of diatoms are Navicula, Pinnularia. Synedra, Frangilaria. Their functions include the maintenance of soil fertility, increasing water retention capacity of soil, prevention of soil erosion due to the fact that they act as cementing agents in binding soil particles. They add organic matter to soil after the cell death and thus increase the amount of organic carbon, while their photo- 
synthetic activity release large quantity of oxygen that facilitate the aeration in submerged soils or oxygenate the soil environment. They also take part in weathering rocks, thus building up the soil structure [19]

Although biomass of all microorganisms living in soil constitutes only several percent of organic matter content, they play an important role in the functioning of entire ecosystems [20]. They take part in soil formation, mineralize organic substances, provide plants with bioavailable compounds, cooperate with plants or may be used as a source of insecticidal substances [21]. One of the most important and most widely studied microbial groups in terms of beneficial effects to soil and plants is the group of Plant Growth Promoting Rhizobacteria (PGPR) [22]. This group includes bacterial species from genera such as Azotobacter, Azospirillum, Bacillus, Burkholderia, Enterobacter, Erwinia, Flavobacterium, Pseudomonas and Rhizobium [23]. Activity of these bacteria significantly increases plant growth and yield due to a variety of mechanisms, such as phytohormone production, symbiotic and asymbiotic $\mathrm{N}_{2}$ fixation, production of siderophores, activity against phytopathogenic microorganisms, synthesis of antibiotics, enzymes and/or fungicidal compounds, as well as solubilization of mineral phosphates and other nutrients [24]. PGPR may improve plant growth, salinity and metal toxicity stress tolerance, as well as they are able to produce phytohormones such as indole-3acetic acid (IAA) [25]. Some PGPR produce the enzyme 1-aminocyclopropane-1-carboxylate (ACC) deaminase, which hydrolyses ACC, the immediate precursor of ethylene in plants. By decreasing its concentration in seedlings and thus its inhibitory effect, these PGPR stimulate seedlings' root length [26]. Figure 1. shows the ways how Plant Growth Promoting Rhizobacteria can stimulate plants. Bacteria from the genus Rhizobium form symbiotic associations with roots of leguminous plants like clovers, peas or alfalfa. These Gram-negative, rod-shaped bacteria infect growing root hairs, forming visible nodules. In this form of symbiosis, plants supply simple carbohydrates to bacteria while bacteria convert nitrogen $\left(\mathrm{N}_{2}\right)$ from air into the forms $\left(\mathrm{NO}_{3}{ }^{-}\right.$or $\left.\mathrm{NH}_{4}{ }^{+}\right)$that plant can use. When leaves or roots from the plant decompose, nitrogen content increases in soil [15]. Some microbial species are capable of detergent decomposition, taking part in self-purification process of soils. Decomposers are particularly important in immobilizing or retaining nutrients in their cells, thus preventing the loss of nutrients, such as nitrogen, from the rooting zone.

Despite beneficial effects of numerous soil microbes on plant growth or development, soil structure and functioning, some soil-dwelling microorganisms may cause plant, animal and human diseases. Similarly to the beneficial soil microflora, soil pathogens include bacteria, fungi and viruses. One of the example of the most important or best known plant pathogens include Agrobacterium tumefaciens (whose updated scientific name is now Rhizobium radiobacter) [27] which is the causal agent of crown gall disease of walnuts, grape vines, stone fruits and many others. These bacteria infect plant roots and induce cells to divide (due to overproduction of auxin and cytokinin), causing a tumor-like swellings that contain infected cells [28]. Erwinia carotovora (or now called Pectobacterium carotovorum) and Erwinia amylovora, the Gram-negative plant pathogens with a diverse host range cause infections of numerous agriculturally and scientifically important plant species, such as potato, apple, pear and some members of the family Rosaceae [29]. Soil is also an abundant source of fungal pathogens. Among them we may 


\section{Biocontrol}

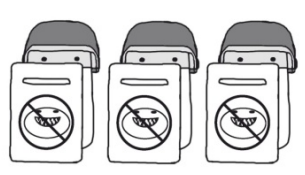

\section{Hormone production}



Nitrogen fixation

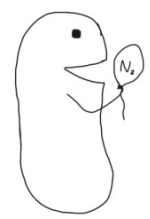

\section{Siderophore production}
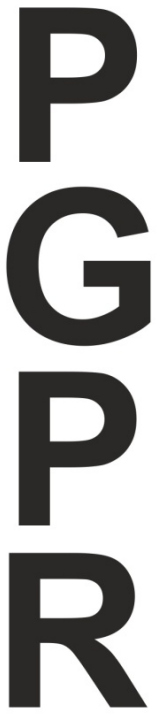

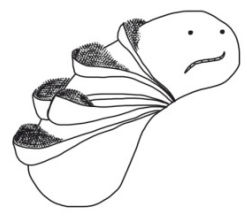

Help in nodulation

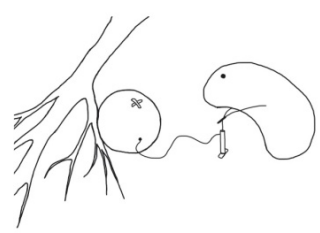

\section{Nutrient uptake}



Figure 1. Summary of mechanisms employed by Plant Growth Promoting Rhizobacteria to stimulate plant development.

distinguish Rhizoctonia solani, a plant pathogenic fungus with a wide host range and worldwide distribution. It causes collar rot, crown rot, root rot, damping off and wire stem [30]. It mainly attacks plant seeds below the soil surface, but may also infect leaves and stems. Due to a variety of hosts that this pathogen attacks, it is of great importance and is detrimental to a variety of crops. The Armillaria root rot, caused by several species of basidoimycete genus Armillariathe honey fungus is, on the other hand, one of the greatest threat for woody plants [31]. Another example of soil-borne plant pathogens is an important genus of fungi - Fusarium, which contains a number of, worldwide distributed, phytopathogenic species [32]. Moreover, Fusarium has also been more recently reported as an emerging human pathogen for immunocompromised patients [33]. Clostridium tetani is an example of one of the most dangerous soilborne human pathogens. It is a tetanus-causing Gram-positive bacterium, whose transmission occurs through the contamination of wounds with soil carrying its spores [34]. Generally, soil is a typical carrier of human bacterial and fungal pathogens. Another example of them is Bacillus anthracis, the causative agent of anthrax, which is found worldwide in a variety of soil 
environments. Inhalation of $B$. anthracis spores can be fatal. Nevertheless, the incidence of both of these fatal diseases has been largely controlled in developed countries due to the development of vaccines [35].

Undoubtedly, soil is an inexhaustible reservoir of microorganisms, both beneficial and pathogenic ones. Causing the imbalance between groups of soil macro- and microorganisms may be irreversible and result in a variety of effects, sometimes unpredictable. Such imbalance may be caused by soil pollution resulting from developing industry, therefore understanding the sources and effects of industrial soil pollution is an important element in preventing the environmental degradation.

\section{Sources of soil heavy metal pollution}

Chemical compounds, entering the ecosystem as a result of different human activities, may accumulate in soil and water environments. Therefore, soil may be regarded as a longterm reservoir of pollutants, from which these compounds may be introduced to food chains or groundwater [36]. Inappropriate and careless disposal of industrial waste often results in environmental pollution. The pollution includes point sources such as emission, effluents and solid discharge from industry, vehicle exhaustion and metal smelting or mining, as well as nonpoint sources (e.g. the use of pesticides or excessive use of fertilizers) [37]. Each of the sources have their own damaging effects on plant, animal and human health, but those that add heavy metals to soils are of serious concern due to the persistence of these elements in the environment. They cannot be destroyed, but are only transformed from one state to another [38].

Soil pollution may be defined as presence of xenobiotics (e.g. chemical compounds, radioactive elements) that alters the soil properties - both chemical, physical and biological. Soil pollution, including heavy metals, may be of natural origin, like volcanic eruptions, animal excrements or ore leaching. Nevertheless, human activity and mostly chemical industry, mining and metallurgy, as well as municipal management and traffic emissions are the main source of environmental pollution. Some authors also mention that waste disposal, waste incineration, fertilizer application and long-term application of wastewater in agricultural lands may result in heavy metal pollution of soils [39].

Heavy metals occur naturally in soils due to pedogenetic processes of weathering parent materials, however concentrations of these metals are regarded as trace $\left(<1000 \mathrm{mg} \times \mathrm{kg}^{-1}\right)$ and rarely toxic [40]. Due to the disturbance and acceleration of the natural slow geochemical cycles of metals by man, most soils of rural and urban environments accumulate one or more heavy metals above the defined background levels, high enough to cause risks to ecosystems [41]. Nevertheless, heavy metals occurring in soils from anthropogenic sources tend to be more mobile, therefore more bioavailable than pedogenic or lithogenic ones [42].

Communication routes, such as roads, railways etc., are an important source of soil pollution, especially in the case of lead and zinc. Despite restricted use of leaded gasoline adopted in 
most countries, lead remains one of the most serious automotive-originating metal pollutant. The areas located nearby roads, particularly in urban sites, are the most vulnerable to automotive pollution. Apart from lead and zinc, chromium, cadmium, nickel and platinum are among the pollutants emitted by combustion engine-powered vehicles [43]. Heavy metals enter the environment as a result of tire wear and damage of vehicle parts. Moreover, grease used in vehicles may also be the source of cadmium pollution along roads [44]. Nickel emission results from this metal being added in gasoline and atmospheric abrasion of nickel-containing parts of automobiles [45]. The changes in the concentrations of lead, nickel, cadmium, copper and zinc in roadside soils are frequently attributed to traffic density [46].

Standard agricultural practices are also a significant source of heavy metals in soils, as application of fertilizers and pesticides has contributed to a continuous accumulation of these elements. Heavy metals can accumulate in soils due to the application of liquid and solid manure, as well as inorganic fertilizers [47]. The application of numerous biosolids, such as livestock manures, composts and municipal sewage sludge on agricultural soils leads to the accumulation of various heavy metals, such as, $\mathrm{Cd}, \mathrm{Cr}, \mathrm{Cu}, \mathrm{Hg}, \mathrm{Mo}, \mathrm{Ni}$, and $\mathrm{Zn}$ [48]. Lime and superphosphate fertilizers contain not only major elements necessary for plant nutrition and growth but also trace metal impurities such as cadmium. The presence of high concentrations of $\mathrm{Cd}$ in some fertilizers (particularly in phosphatic fertilizers) is of most concern due to the toxicity of this metal and its ability to accumulate in soils as well as due to its bioaccumulation in plant and consequently in animal tissues $[49,50]$. Additionally, copper-containing compounds have been widely used in agricultural practice as pesticides. Copper oxychloride is annually applied on vineyards as a fungicide to control a significant number of plant diseases. Inevitably, this $\mathrm{Cu}$ ends up in the agricultural soil and adjacent pristine natural vegetation [51]. Lead arsenate was used in fruit orchards for many years to control some of the parasitic insects. Arsenic-containing compounds were also extensively used to control pests in banana plantations in new Zealand and Australia [52]. High fertilizer applications and acid atmospheric deposition, combined with insufficient liming, may also cause a decrease in $\mathrm{pH}$ and thus increase heavy metal bioavailability, aggravating the problem of deteriorating food quality, metal leaching and impact on soil organisms [53]. The application of municipal wastewater or industrial waste as fertilizers and liming agents in agriculture is a separate issue. Application of this type of waste requires constant monitoring of the amount and proportion of harmful factors, including heavy metals. The high risk of soil pollution with $\mathrm{Cd}, \mathrm{Zn}, \mathrm{Ni}$ and $\mathrm{Pb}$ as a result of industrial waste application as fertilizers was also evidenced [50].

Airborne sources of heavy metals include stack emissions or fugitive emissions such as dust from storage areas or waste heaps. Stack emissions can be distributed over a wide area by natural air currents, while fugitive emissions are often distributed over much smaller areas. In general, concentrations of pollutants are much lower in fugitive emissions compared to stack emissions. The type and concentration of metals emitted from both types of sources depend on site-specific conditions. All solid particles in smoke from fires and other emissions from factory chimneys are deposited on land or sea. Most forms of fossil fuels contain some heavy metals and this form of environmental pollution has been increasing since the industrial revolution began. For instance, very high concentrations of $\mathrm{Cd}, \mathrm{Pb}$ and 
Zn have been found in plants and soils adjacent to smelting plants. Another major source of soil pollution is the aerial emission of lead from combustion of petrol containing tetraethyl lead; this contributes substantially to the content of $\mathrm{Pb}$ in soils in urban areas and in those adjacent to major roads [52].

Another, and one of the most significant sources of heavy metal pollution of soils, includes heavy industry, e.g. mining and metallurgy. Industrial airborne heavy metal contamination of the nonferrous smelters surrounding landscapes is a well-known and widely occurring phenomenon. Emissions of metallurgical dust are spread according to the wind direction and particle size while soil is the main receiver of heavy metals in dry land. Dust emissions from smelters using sulfide copper-nickel ores are similar, regardless of their location, owing to the fact that the same raw materials are used in metallurgical processes. The following major metalcontaining compounds are deposited onto the landscape in the form of dust emissions from smelters: pentlandite (Ni,Fe)9S8, pyrrotite Fe7Sg(Nix), chalcopyrite CuFeS2, chalcosite Cu2S, covellite $\mathrm{CuS}$, cuprite $\mathrm{Cu} 20$, tenorite $\mathrm{CuO}$, and metal copper and nickel [54]. Surface soil layers in the mining or metallurgy areas are often heavily polluted with copper. In the vicinities of steel plants the concentration of this element exceeds several thousand ppm and the pollution remains for a long time, even after the operation of mines or steel plants had been stopped [50]. The fine fractions of dust are enriched with lead, arsenic, and zinc. The quantity and composition of dust derived from different sources (metallurgical processes) varies according to the raw materials and the condition of the gas cleaning systems [54]. The cause for the frequently widely dispersed metal pollution in habitats of mining areas was found in the formation of acid mine drainage (AMD). The runoff from mining heaps of active and abandoned mines can be extremely acidic, with $\mathrm{pH}$ values reaching as low as $\mathrm{pH} 2$ [9]. Chemical and biological oxidation of the abundant mineral pyrite $\left(\mathrm{FeS}_{2}\right)$ occurs after the unearthing of pyrite-containing rock formations and results in an acidification of the dump material [55]. Under acidic conditions, the majority of heavy metals is leached from the waste dump and they are transported as AMD in streamwaters [9]. Galvanization industry may cause soil pollution with silver as well as other industrial facilities that use silver salts. Additionally, the increased amount of silver may by introduced to soils with municipal sewage. Municipal sewage contains also large amounts of highly soluble forms of zinc, which may then easily contaminate soil environment [50]. Zinc is also extensively used in metallurgical industry, as an anticorrosion agent in alloys and in galvanization. It is frequently used in paint industry [50]. The concentration of cadmium highly increases in soils polluted with emissions from nonferrous metal plants, which constitute over $60 \%$ of all anthropogenic sources of this element in soils. Municipal sewage contains on average $10-40$ ppm of cadmium, while industrial sewage may contain over $1000 \mathrm{ppm}$. This is also a case of large amounts of lead that may be introduced into soils from municipal sewage and waste, as they contain mobile forms of this element. This may result in large increase in the concentration of lead in soils that may exceed several times the admissible limits. Additionally, dust emissions from landfills of nonferrous metal plants may become dangerous sources of lead in soils [50]. Table 2 shortly summarizes the major sources of different heavy metals in soil. 


\begin{tabular}{ll}
\hline Heavy metals & \multicolumn{1}{c}{ Sources } \\
\hline $\mathrm{As}$ & $\begin{array}{l}\text { Semiconductors, petroleum refining, wood preservatives, animal feed additives, coal power } \\
\text { plants, herbicides, volcanoes, mining and smelting }\end{array}$ \\
\hline $\mathrm{Cu}$ & Electroplating industry, smelting and refining, mining, biosolids \\
\hline $\mathrm{Cr}$ & $\begin{array}{l}\text { Geogenic sources, anthropogenic activities, metal smelting and refining, fossil fuel burning, } \\
\text { application of phosphate fertilizers, sewage sludge }\end{array}$ \\
\hline $\mathrm{Pb}$ & Electroplating industry, sludge, solid waste, tanneries \\
\hline $\mathrm{Hg}$ & Mining and smelting of metalliferous ores, burning of leaded gasoline, municipal sewage, \\
& industrial wastes enriched in Pb, paints \\
\hline $\mathrm{Se}$ & Volcano eruptions, forest fire, emissions from industries producing caustic soda, coal, peat and \\
\hline $\mathrm{Ni}$ & Coal mining, oil refining, combustion of fossil fuels, glass manufacturing industry, chemical \\
\hline $\mathrm{Zn}$ & Synthesis (e.g., varnish, pigment formulation) \\
\hline & Solcanic eruptions, land fill, forest fire, bubble bursting and gas exchange in ocean, weathering of \\
\hline
\end{tabular}

Table 2. Different sources of heavy metals in soils [56]

\section{The effects of heavy metals on soil microorganisms}

Metals without biological function are generally tolerated only in minute concentrations, whereas essential metals with biological functions, are usually tolerated in higher concentrations [9]. They have either metabolic functions as constituents of enzymes or meet structural demands, e.g. by supporting the cell envelope. Frequently the concentration and the speciation of metal determine whether it is useful or harmful to microbial cells [9].

Microorganisms are the first biota that undergoes direct and indirect impacts of heavy metals. Some metals (e.g. Fe, Zn, Cu, Ni, Co) are of vital importance for many microbial activities when occur at low concentrations. These metals are often involved in the metabolism and redox processes. Metals facilitate secondary metabolism in bacteria, actinomycetes and fungi $[9 ; 57]$. E.g. chromium is known to have stimulatory effect on both actinorhodin production and growth yield of the model actinomycete S. coelicolor [58]. However, high concentrations of heavy metals may have inhibitory or even toxic effects on living organisms [59]. Adverse effects of metals on soil microbes result in decreased decomposition of organic matter, reduced soil respiration, decreased diversity and declined activity of several soil enzymes [60]. Some of the general changes in morphology, the disruption of the life cycle and the increase or decrease of pigmentation are easy to observe and evaluate [9]. Rajapaksha et al. [61] compared the reactions of bacteria and fungi to toxic metals in soils $(\mathrm{Zn}$ and $\mathrm{Cu})$. They concluded, that bacterial community is more sensitive to increased concentrations of heavy metals in soils than 
the fungal community. The relative fungal/bacterial ratio increased with increasing metal levels. Those authors also noticed the varying effect of soil $\mathrm{pH}$ on the microbial reaction to soil pollution, i.e. that lower $\mathrm{pH}$ in contaminated soils enhanced the negative effect on bacteria, but not on fungi.

The toxic concentration of heavy metals may cause enzyme damage and consequently their inactivation, as the enzymes-associated metals can be displaced by toxic metals with similar structure [59]. Moreover, heavy metals alter the conformational structures of nucleic acids and proteins, and consequently form complexes with protein molecules which render them inactive. Those effects result in disruption of microbial cell membrane integrity or destruction of entire cell [62]. Heavy metals also form precipitates or chelates with essential metabolites [63].

Various metals may affect different microbial populations and the resulting impact may vary depending on the metal whose limit concentrations in soils were exceeded. For instance, the pollution of soils with copper affects microorganisms that take part in nitrification and mineralization of protein compounds [50]. Silver is one of the most toxic metals to heterotrophic bacteria. This effect is used for the production of antiseptic preparations. However, there are some silver-resistant bacteria, both in clinical and natural conditions. Some strains of Thiobacillus ferrooxidans are able to accumulate particularly large amounts of silver [50]. About $100 \mathrm{ppm}$ of zinc in soils may inhibit nitrification processes and about $1000 \mathrm{ppm}$ inhibits the majority of microbiological processes in soils [64]. Microorganisms play vital role in circulation and transformation of mercury compounds in the environment. Numerous bacteria and fungi show high tolerance (also acquired) to increased concentrations of mercury in soils. However, some microorganisms are sensitive to excess mercury, e.g. the concentration of $<10 \mathrm{ppm} \mathrm{Hg}$ may have toxic effects on nitrifiers in soils [50]. Increased concentrations of lead in surface soil layers negatively affect soil microflora. Processes of organic matter decomposition, particularly cellulose, are inhibited as a result of decreased enzymatic activity of microorganisms. This results in soil degradation. Biosorption of lead by soil microorganisms reaches on average $0.2 \%$ of this metal, but in some cases it may reach even $40 \%$ of biomass and may be used for biological remediation [50]. Some studies indicate that long-term contamination of soils with heavy metals has adverse effects on soil microbial activity. For instance, Juwarkar et al. [65] while researching the remediation strategies for cadmium and lead contaminated soils, compared the numbers of the selected groups of microorganisms in natural and heavy metal spiked soils. The results that they obtained indicated that the examined microbial groups were much less abundant in contaminated soils than in natural ones [Table 3]. On the other hand, Lenart and Wolny-Koładka [66] recorded significantly variable numbers of the selected microbial groups while analyzing the uncontaminated and heavy metal contaminated soils of ArcelorMittal steelworks in Cracow. Similarly, their results indicated that except for fungi, the soil-dwelling microorganisms were much less abundant in heavy metal polluted soils than in uncontaminated soils (Table 4). Heavy metal contamination results in reduction of microbial biomass and even if they do not cause the reduction in their number - they reduce biodiversity or disturb the community structure [64]. 


\begin{tabular}{lcc}
\hline Analyzed microorganisms $\left[\mathrm{CFU} \times \mathbf{g}^{-1}\right]$ & Natural soil & Heavy metal contaminated soil \\
\hline Total number of bacteria & $17 \times 10^{5}$ & $58 \times 10^{4}$ \\
\hline Total number of fungi & $26 \times 10^{3}$ & $42 \times 10^{2}$ \\
\hline Actinomycetes & $43 \times 10^{3}$ & $18 \times 10^{1}$ \\
\hline Azotobacter spp. & $23 \times 10^{3}$ & $17 \times 10^{1}$ \\
\hline Rhizobium spp. & $21 \times 10^{3}$ & $16 \times 10^{2}$ \\
\hline
\end{tabular}

Table 3. Microbiological characteristics of natural and heavy metal spiked spoil samples in Nagpur (India) [65]

\begin{tabular}{lcc}
\hline Analyzed microorganisms $\left[\mathrm{CFU} \times \mathbf{g}^{-1}\right]$ & Uncontaminated soil & Heavy metal contaminated soil \\
\hline Total number of mesophilic bacteria & $22.50 \times 10^{2}-10.44 \times 10^{6}$ & $0-13.15 \times 10^{5}$ \\
\hline Total number of fungi & $84.00 \times 10^{1}-21.03 \times 10^{3}$ & $0-57.90 \times 10^{3}$ \\
\hline Actinomycetes & $62-99.50 \times 10^{3}$ & $0-20.26 \times 10^{3}$ \\
\hline Azotobacter spp. & $0-28.90 \times 10^{2}$ & $0-57.00 \times 10^{1}$ \\
\hline
\end{tabular}

Table 4. Ranges of the selected microbial groups in heavy metal contaminated and uncontaminated soils of ArcelorMittal steelworks in Cracow, Poland [66].

However, one of the reasons of decreasing biodiversity of microorganisms in heavy metal polluted soils is the selection for tolerant species or strains. Metal exposure may lead to the establishment of tolerant microbial populations, that are often represented by several Grampositive genera such as Bacillus, Arthrobacter and Corynebacterium or Gram-negatives, e.g. Pseudomonas, Alcaligenes, Ralstonia or Burkholderia [68]. It was shown that the impact of heavy metals on the bacterial metabolism depends on the growth form. The resistance towards metals seems higher in consortia than in pure cultures [69]. A great number of heavy metal-resistant bacteria, such as e.g. Cupriavidus metallidurans possess efflux transporters that excrete toxic or overconcentrated metals outside the cell [70]. Efflux transporters have high substrate affinity and can therefore maintain low cytosolic concentration of metals [9]. Alternatively, microbial cells may prevent the intoxication by the release of metal-binding compounds into the extracellular surroundings. In that case, metals are chelated outside the cell and thus blocked from entering the cell through the membrane transporters that otherwise facilitate the influx [9]. Some fungal and bacterial species are able to keep metals outside their cells by the extracellularly active melanin [71]. It is a secondary metabolite that has strong cation chelating properties through the anionic function such as carboxyl and deprotonated hydroxyl groups [9]. A substantial number of soil microorganisms, such as widespread fungus Aspergillus niger, solubilize metals by the release of organic acids or by the immobilization of metals through excretion of different compounds, such as oxalates [72]. Some microorganisms possess the abilities to protect their cells by a cytosolic sequestration mechanisms. These mechanisms are activated once the metal enters the cell and cannot be excreted. In this case internal inclusion bodies, e.g. polyphosphate granules (volutin) bind large amounts of metal cations [73]. 
Investigation and understanding of microbial resistance mechanisms towards heavy metals are crucial for the potential application of microorganisms for remediation of polluted soils.

\section{General outline of soil remediation strategies}

The overall objective of any soil remediation approach is to create a final solution that is protective both for human health and the environment [74]. For heavy metal-polluted soils, the physical and chemical form of the heavy metal contaminant in soil strongly influences the selection of the appropriate remediation treatment approach. Details on the physical characteristics of polluted soils, type and level of the pollution at the site must be known to enable accurate assessment of the problem severity and adjustment of remedial measures [52].

Remediation of heavy metal-polluted sites is very expensive and difficult, therefore the best method to protect the environment from contamination is to prevent it. Nevertheless, it is not always possible and once metals are introduced and pollute the soil, they will remain there. Unlike carbon-based organic pollutants, heavy metals cannot be degraded or eliminated completely, therefore the traditional treatments for heavy metal pollution of soils are complicated and cost-intensive.

There are several technologies for remediation of heavy metal-polluted soils. One of the classifications divides the methods into in situ and $e x$ situ treatment technologies. In situ (in place) means that the polluted soil is treated in its original location, i.e. it remains at the site or in the subsurface. Such technologies remove the pollutant from soil without excavation or removal of the soil. In this case fixing agents are applied on the unexcavated soil. This technique's advantages may include low invasiveness, simplicity and rapidity. Moreover, it is fairly inexpensive and generates relatively low amount of waste. However, it is only a temporary solution. This is due to the fact that when physicochemical properties of soil change, the pollutants may again become active. Moreover, the reclamation process is applied only to the surface layer of soil [75]. Ex situ means that the treated soil is removed or excavated from the site [52]. It is applied in areas where heavily polluted soil must be removed from its place of origin and its storage is associated with high ecological risk. Fast and easy applicability, relatively low costs of investment and operation are the advantages of this method. On the other hand, it is highly invasive to the environment, generates a significant amount of solid wastes, and it is necessary to control the stored waste permanently. Evanko and Dzombak [76] divide in situ remediation strategies into solidification/stabilization, vitrification, soil flushing, electrokinetic extraction and biological treatment. Ex situ treatment technologies are divided by these authors into: solidification/stabilization, soil washing, vitrification and pyrometallurgical separation. Another classification of remedial strategies divides the technologies under five categories of general approaches to remediation: isolation, immobilization, toxicity reduction, physical separation, and extraction. There are several physicochemical techniques that include excavation and burial of soil at a hazardous waste site, chemical processing of soil to immobilize metals, leaching by using acid solutions or appropriate leachants to desorb metals from soil followed by the return of clean soil to the site [77], precipitation or flocculation 
followed by sedimentation, ion exchange, reverse osmosis and microfiltration [78]. Nevertheless, physicochemical techniques for heavy metal remediation are generally costly and have side effects [37]. Therefore, continuous efforts have been made to develop techniques that are easy to use, sustainable and economically feasible.

\section{The use of plants for biological remediation of heavy metal polluted soils}

Phytoremediation is one of the best techniques for treatment of heavy metal-polluted sites. It is an in situ strategy that uses vegetation and associated microbiota together with agronomic practices to aid in metal remediation [79]. It is based on the use of special type of plants to decontaminate soil by inactivating metals in the rhizosphere or translocating them in the aerial parts [56]. Some plants developed mechanisms to remove ions selectively from the soil to regulate the uptake and distribution of metals. Potentially useful phytoremediation technologies for heavy metal-polluted sites include phytoextraction, phytostabilization and rhizofiltration [75].

Phytoextraction uses hyperaccumulating plants to remove metals from soil by absorption into the roots and shoots of the plant. The aboveground shoots can be then harvested to remove metals from the site and subsequently stored as hazardous waste or employed for the recovery of metals. The ideal plant for phytoextraction should grow rapidly, produce high amount of biomass and be able to tolerate and accumulate high metal concentrations in shoots [80]. Hyperaccumulating plants belong to the families of Brassicaceae, Fabaceae, Euphorbiaceae, Asterraceae, Lamiaceae, and Scrophulariaceae [77]. Studies indicate that many Brassica species, such as B. juncea, B. napus or B. rapa exhibit enhanced accumulation of $\mathrm{Zn}$ and $\mathrm{Cd}$ [81] In comparison to conventional methods like e.g. soil excavation (ex situ remediation), phytoextraction is time consuming, but on the other hand it is cost-effective and less labor-intensive [9].

Phytostabilization is based on the use of plants to limit the mobility and bioavailability of metals in soil. Plants used in this method are characterized by high tolerance of metals in surrounding soils together with their low accumulation. Phytostabilization can be carried out through the process of sorption, precipitation, complexation, or metal valence reduction. This technique is useful for the removal of $\mathrm{Pb}, \mathrm{As}, \mathrm{Cd}, \mathrm{Cr}, \mathrm{Cu}$, and $\mathrm{Zn}$ [82]. This process is advantageous because in this case disposal of hazardous material/biomass is not required, and it is very effective when rapid immobilization is needed to preserve soils or ground and surface waters [82].

Rhizofiltration (or phytofiltration) removes metals from contaminated soil via absorption, concentration and precipitation by plant roots. This technique is used to remove pollutants from groundwater and aqueous-waste streams rather than for the remediation of polluted soils [76]. Apart from the above described phytoremediation methods, some authors [83] include also phytovolatization and phytodegradation.

Phytovolatization involves the use of plants to volatilize pollutants from their foliage such as Se and $\mathrm{Hg}$, while phytodegradation uses plants and associated microorganisms to degrade 
organic pollutants. Even though phytoremediation strategies are inexpensive, effective, environmentally friendly and can be implemented in situ, a substantial proportion of metal pollutants are unavailable for root uptake by field grown plants [84]. Therefore, methods of increasing phytoavailability of heavy metal pollutants in soil and their transport to plant roots are vital to the success of in situ phytoremediation. In this case it is useful to apply microbial populations that are able to affect trace metal mobility and availability to plants, through the release of chelators, acidification and redox changes [85]. It was proved that the presence of rhizosphere bacteria increases the available concentrations of various heavy metals to hyperaccumulative plants [80]. Microbial populations may be used not only for increasing metal bioavailability to plants, but also for the promotion of hyperaccumulative plant growth through $\mathrm{N}_{2}$ fixation, production of phytohormones and siderophores, and transformation of nutrients [26]. Figure 2 summarizes the mechanisms of plant-mediated remediation of contaminated soils.

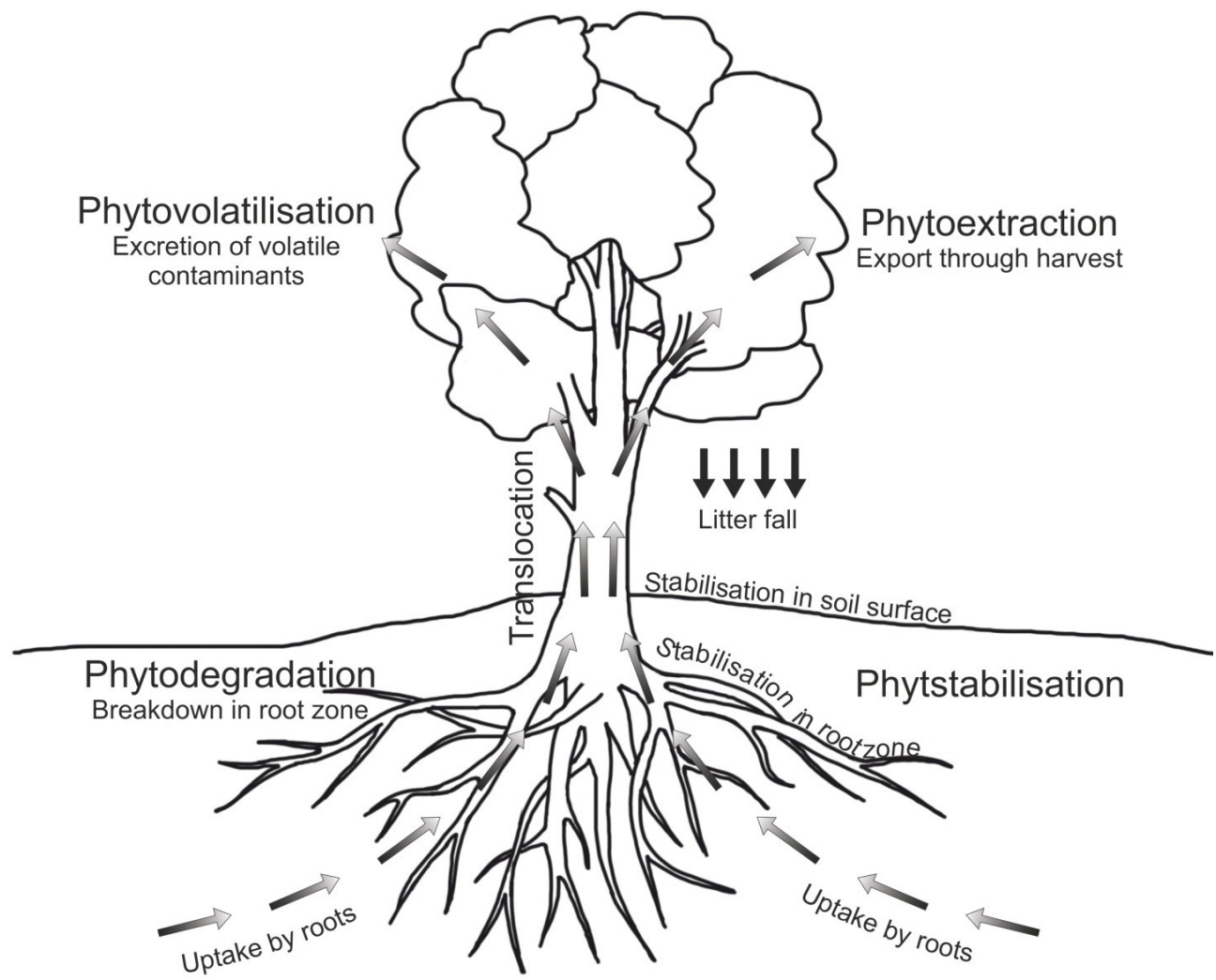

Figure 2. Mechanisms of phytoremediation involved in purifying contaminated soils and physiological processes that occur in plants during phytoremediation. 


\section{Application of microorganisms to remediate heavy metal-polluted soils}

Another approach for biological remediation of heavy metal-polluted soils includes the use of microorganisms to detoxify metals by valence transformation, extracellular chemical precipitation or volatilization etc. [56]. Bioleaching is the method that uses microorganisms to solubilize heavy metal pollutants either by direct bacterial processes, or as a result of interactions with metabolic products, or both [76]. It can be used in situ or ex situ to help to remove the pollutants from soils. This process is based on mobilization of metal cations from insoluble ores by biological oxidation and complexation. This process was adapted from mining industry for the use in soil remediation and a general term covering both bioleaching and biooxidation techniques could be "biomining". This technique is mainly employed for copper, cobalt, nickel, zinc and uranium, which are extracted either from insoluble sulfides or (in the case of uranium) from oxides [86]. The classical bioleaching bacteria belong to the genus Acidithiobacillus (A. thiooxidans and A. ferrooxidans), Acidiphilium, Acidimicrobium, Ferromicrobium or Sulfobacillus [86].

Another solution for soil bioremediation using microorganisms is to apply microbiallymediated biochemical processes, such as oxidation/reduction or methylation reactions [87]. Often, biostimulation and bioaugmentation are the components of bioremediation strategies. Biostimulation is a form of in situ bioremediation which uses growth rate stimulation nutrients, electron donors or acceptors to encourage the growth of site-specific indigenous microorganisms capable of degrading environmental pollutants. Common electron donors and acceptors used in biostimulation include: acetate, sulfate, nitrate and ethanol [88]. Bioaugmentation is the introduction of specific competent microorganisms to the local microbial population in order to increase the metabolic capacities needed for remediation [89]. Biosorption is a physicochemical process that occurs naturally and allows to passively concentrate and bind contaminants onto the microbial cell structure [90]. Metal biosorption by living organisms is a complicated process that consists of two steps. In the first step, metal ions are adsorbed on the cell surface by interactions between metals and cell surface functional groups. Biosorption of metal ions occurs primarily on the outer surface of microbial cells and is the first step in the interactions between metals and microbial cell walls [4]. The cell wall consists of a variety of polysaccharides and proteins, and hence offers a number of active sites capable of binding metal ions [91]. Differences in the cell wall composition among various microbial groups, i.e. algae, bacteria, cyanobacteria and fungi, cause significant differences in the type and amount of metal ions binding to them [91]. Physical adsorption via electrostatic or van der Waals forces allow to retain metal ions on the outer surfaces of bacterial cells. In addition to physical adsorption, ion exchange and complexation are believed to be the dominant mechanisms involved in metal biosorption [4]. The first step, passive biosorption, is metabolism-independent and proceeds rapidly by any one or a combination of metal binding mechanisms. In the second step, due to active biosorption, metal ions penetrate the cell membrane and enter into the cells. This is, however, a slowly occurring process. Active mode is metabolism-dependent and related to metal transport and deposition [91]. There are several microbial genera and species capable of metal biosorption. Fungi were found to be efficient biosorbent organisms, as their cells are characterized by a high percentage of cell wall material, which shows excellent 
metal binding properties [92]. Aureobasidium pullulans, Cladosporium resinae, Aspergillus niger, Aspergillus versicolor or Rhizopus nigricans are the fungal species proved to be effective in heavy metal biosorption [91]. Numerous studies also identified several species of bacteria as efficient metal accumulating microorganisms. For instance, Bacillus spp. has been reported to have a high potential of metal sequestration and has been used in commercial biosorbent preparation [91]. Other bacterial species capable of metal transformation include, among others: Escherichia coli, Pseudomonas maltophilia, Shewanella putrefaciens, Pseudomonas aeruginosa, Enterobacter cloacae [4].

Mechanisms involved in biochemical interactions between bacteria and metal ions involve specific enzymes that catalyze the oxidation, reduction, methylation, dealkylation and precipitation reactions. Microorganisms transform a substantial number of metals and metalloids by reducing or oxidizing them directly to a lower or higher redox state. Additionally, indirect oxidation or reduction is an alternative for immobilization of toxic metals in the environment. Methylation is an important process involved in geochemical cycling of metals and the removal of metal pollutants from soils. Methylation processes derive the methyl group from methylocarbolamine $\left(\mathrm{CH}_{3} \mathrm{~B}_{12}\right)$ which is implicated in the methylation of multiple metals and metalloids, such as Pb, Sn, Pd, Pt, Au, Ti, As, Se and Te [93]. Methylation of Hg, Sn and $\mathrm{Pb}$ can be mediated by a range of microbes, including Clostridium spp., methanogens and sulfate-reducing bacteria under anaerobic conditions and principally by fungi (e.g. Penicillium spp. and Alternaria spp.) under aerobic conditions. Methyl groups are enzymatically transferred to metals and a given species may transform a number of different metals [94]. Methyl-metal compounds are generally highly volatile and available to plants [50]. Another mechanism that has the potential for the application in heavy metal-polluted sites is the production of siderophores by different microbial genera. Siderophores are the largest class of compounds that can bind and transport Fe. They are highly specific Fe(III) ligands and are excreted by a wide variety of fungi and bacteria to aid Fe assimilation [94].

Microorganisms play an important role in the environmental biogeochemical cycle of metals and their properties are of significant interest in the remediation of contaminated sites. The microbial ability to absorb and transform metals is a promising aspect in respect of solving the pollution problems [4]. The potential of numerous microbial metal transformations in treatment of environmental pollution may be employed and some processes are already in commercial operation. However, many processes are still at the laboratory scale and yet to be tested in a rigorous applied and/or commercial context [94]. Another interesting aspect of the microbial community is their ability to multiply even under undesirable environmental conditions. These microorganisms sometimes affect soil environment more quickly than abiotic processes can. Therefore, the structure of soil microbial populations may be useful as a highly sensitive bioindicator of soil disturbance and progress of remediation [95].

Facing the increasing heavy metal pollution severity accompanied by rising land prices the communities around the world need to struggle for available investment grounds. This is mostly the problem of big cities, especially those with limited opportunities for development due to geographical barriers such as seashores, mountain ranges or desert areas. In such situations the polluted industrial areas cannot be left unused for long time to recover naturally. 
This creates a need for the development of various remedial procedures adjusted to changing contamination level, environmental conditions, available time and funding. Thus, remedial measures need to be almost always modified in order to meet those criteria. This makes that the continuous effort should be made to increase the effectiveness, flexibility and decrease the cost and side effects of the procedures available today. Although a number of measures was developed to remove the even toxic level of contamination, there are many degenerated areas that still cannot be successfully treated now. Those cases involve sites where remediation would be too expensive, time consuming or even technically disputable with currently available treatment procedures.

\section{Conclusion}

Heavy metals pose a significant threat towards the soil environment and the rapid industrialization will result in increasing problems of environmental pollution. Therefore, it is necessary to carry out the continuous monitoring of both industrial areas and their vicinities for possible transgressions of the limits given by the authorities. When necessary, the remedial measures should be applied as soon as possible by all available means. On the other hand, research should be promoted to understand the mechanisms of microbial response to heavy metal pollution and to enable screening for possible resistant microorganisms that could be used for both remediation and restoration of soil environment fertility.

\section{Author details}

Anna Lenart-Boron ${ }^{1}$ and Piotr Boron ${ }^{2}$

*Address all correspondence to: annalenart82@gmail.com

1 Department of Microbiology, Faculty of Agriculture and Economics, University of Agriculture in Cracow, Cracow, Poland

2 Department of Forest Pathology, Faculty of Forestry, University of Agriculture, Cracow, Poland

\section{References}

[1] Ehrlich H.L. Geomicrobiology. $4^{\text {th }}$ ed. New York: Marcel Dekker; 2002.

[2] Appenroth K.J. Definition of "heavy metals" and their role in biological systems. In: Sherameti I., Varma A. (eds.) Soil heavy Metals, Soil Biology. Berlin: Springer; 2010. P. 19: 19-29. 
[3] Szyczewski P., Siepak J., Niedzielski P., Sobczyński T. Research on heavy metals in Poland. Polish Journal of Environmental Studies 2009; 18: 755-768.

[4] Han X., Gu J.D. Sorption and transformation of toxic metals by microorganisms. In: Mitchell R., Gu J.D. (eds.) Environmental Microbiology $2^{\text {nd }}$ ed. New Jersey: WileyBlackwell; 2010. p. 153-175.

[5] Tate R.L. Soil Microbiology. $2^{\text {nd }}$ ed. Hoboken: John Wiley and Sons Inc. USA; 2000.

[6] McKinney R. E. Environmental Pollution Control Microbiology. New York: Marcel Dekker, Inc.; 2004.

[7] Roselló-Mora R., Amann R. The species concept for prokaryotes. FEMS Microbiology Reviews 2001; 25: 39-67.

[8] Metting F.B. Soil Microbial Ecology. New York: Marcel Dekker Inc.; 1993.

[9] Hafeburg G., Kothe E. Microbes and metals: interactions in the environment. Journal of Basic Microbiology 2007; 47:453-467.

[10] Ranjard L., Richaume A. Quantitative and qualitative microscale distribution of bacteria in soil. Research in Microbiology 2001; 152: 707-716.

[11] Torsvik V., Øvreås L. Microbial diversity and function in soil: from genes to ecosystems. Current Opinion in Microbiology 2002; 5:240-245.

[12] Sessitsch A., Weilhalter A., Gerzabek M.H., Kirchmann H., Kandeler E. Microbial population structures in soil particle size fractions of a long-term fertilizer field experiment. Applied Environmental Microbiology 2001; 67: 4215-4224.

[13] Grayston S.J., Griffith G.S., Mawdsley J.L., Campbell C.D., Bardgett R.D. Accounting for variability in soil microbial communities of temperate upland grassland ecosystems. Soil Biology and Biochemistry 2001; 33: 533-551.

[14] Fierer N., Jackson R.B. The diversity and biogeography of soil bacterial communities. Proceedings of the National Academy of Sciences 2006; 103: 626-631.

[15] Hoorman J.J. The Role of Soil Bacteria. Fact Sheet - Agriculture and Natural Resources. The Ohio State University; 2011.

[16] Agriinfo. Soil Microorganism: Bacteria. http://agriinfo.in/default.aspx?page=topic\&superid=5\&topicid=147 (accessed 10 July 2013)

[17] Jenkins A. Soil fungi. In: Soil biology basics. State of New South Wales, Department of Primary Industries; 2005. http://www.dpi.nsw.gov.au/_data/assets/pdf_file/ 0020/41645/Soil_fungi.pdf (accessed 20 June 2013).

[18] Schlegel H.G. General microbiology. Cambridge: Cambridge University Press; 1993.

[19] Agriinfo. Soil Microorganism: Algae. http://agriinfo.in/?page=topic\&superid=5\&topicid=150 (accessed 10 July 2013). 
[20] Barabasz W., Albińska D., Jaśkowska M., Lipiec J. Biological effects of mineral nitrogen fertilization on soil microorganisms. Polish Journal of Environmental Studies 2002; 11: 193-198.

[21] Lynch J.M. The terrestrial environment. In: Lynch J.M., Hobbie J.E., (eds.) Microorganisms in Action: Concepts and Applications in Microbial Ecology. Oxford: Blackwell; 1988. p. 67-91.

[22] Kloepper J.W., Leong J., Teintze M., Schroth M.N. Enhanced plant growth by siderophores produced by plant growth-promoting rhizobacteria. Nature 1980; 286: 885-886

[23] Rodriguez H., Fraga R. Phosphate solubilizing bacteria and their role in plant growth promotion. Biotechnology Advances 1999; 17: 319-339.

[24] Gholami A., Shahsavani S., Nezarat S. The effect of Plant Growth Promoting Rhizobacteria (PGPR) on germination, seedling growth and yield of maize. World Academy of Science, Engineering and Technology 2009; 25: 19-24.

[25] Do Vale Barreto Figueiredo M., Seldin L., de Araujo F.F., de Lima Ramos Mariano R. Plant Growth Promoting Rhizobacteria: fundamentals and applications. In: Maheshwari D.K. (ed.) Plant Growth Promoting Bacteria, Microbiology Monographs 18, Berlin Heidelberg: Springer-Verlag; 2010. p. 21-43.

[26] Glick B.R., Patten C.L., Holgin G., Penrose D.M. Biochemical and genetic mechanisms used by plant growth promoting bacteria. London: Imperial College Press; 1999.

[27] Young J.M., Kuykendall L.D., Martínez-Romero E., Kerr A., Sawada H. A revision of Rhizobium Frank 1889, with an emended description of the genus, and the inclusion of all species of Agrobacterium Conn 1942 and Allorhizobium undicola de Lajudie et al. 1998 as new combinations: Rhizobium radiobacter, R. rhizogenes, $R$. rubi, R. undicola and R. vitis. International Journal of Systematic and Evolutionary Microbiology 2001; 51:89-103.

[28] Viss W.J., Pitrak J., Humann J., Cook M., Driver J., Ream W. Crown-gall-resistant transgenic apple trees that silence Agrobacterium tumefaciens oncogenes. Molecular Breeding 2003; 12: 283-295.

[29] Toth I.K., Bell K.S., Holeva M.C., Birch P.R. Soft rot erwiniae: from genes to genomes. Molecular Plant Pathology 2003; 4: 17-30.

[30] Koike S.T., Subbarao K.V., Davis R.M., Turini T.A. Vegetable diseases caused by soilborne pathogens. Publication 8099 of the regents of the University of California, Division of Agriculture and Natural Resources, US; 2003. http:// anrcatalog.ucdavis.edu/pdf/8099.pdf (accessed 21 June 2013). 
[31] Williams R.E., Shaw III C.G., Wargo P.M., Sites W.H. Armillaria Root Disease. Forest Insect and Disease Leaflet 78. U.S. Department of Agriculture Forest Service; 1989. http://na.fs.fed.us/spfo/pubs/fidls/armillaria/armillaria.htm (accessed 16 July 2013).

[32] Moss M.O., Smith J.E. The applied mycology of Fusarium. Cambridge: Cambridge University Press; 1984.

[33] Vartivarian S.E., Anaissie E.J., Bodey G.P. Emerging fungal pathogens in immunocompromised patient: classification, diagnosis and management. Clinical Infection and Disease 17 (Suppl 2) 1993; S487-491.

[34] Ryan J.R. Clostridium, Peptostreptococcus, Bacteroids, and other Anaerobes. In: Ryan K. J., Ray C. G. (eds.) Sherris Medical Microbiology: An Introduction to Infectious Diseases $4^{\text {th }}$ ed.. Columbus: McGraw-Hill; 2004. pp. 309-326.

[35] Maier R.M., Pepper I.L., Gerba C.P. Environmental Microbiology. Philadephia: Elsevier Inc.; 2009.

[36] Pečiulyté D., Dirginčiuté-Volodkiené V. Effect of long-term industrial pollution on soil microorganisms in deciduous forests situated along a pollution gradient next to a fertilizer factory. Ekologija 2009; 55: 67-77.

[37] McGrath S.P., Zhao F.J., Lombi E. Plant and rhizosphere process involved in phytoremediation of metal-contaminated soils. Plant and Soil 2001; 232: 207-214.

[38] Gisbert C., Ros R., de Haro A., Walker D.J., Pilar Bernal M., Serrano R., Avino J.N. A plant genetically modified that accumulates $\mathrm{Pb}$ is especially promising for phytoremediation. Biochemical and Biophysical Research Communications 2003; 303: 440-445.

[39] Bilos C., Colombo J.C., Skorupka C.N., Rodriguez Presa M.J.. Sources, distribution and variability of airborne trace metals in La Plata City area, Argentina. Environmental Pollution 2001; 111: 149-158.

[40] Pierzyński G.M., Sims J.T., Vance G.F. Soils and Environmental Quality. London: CRC Press; 2000.

[41] D'Amore J.J., Al-Abed S.R., Scheckel K.G., Ryan J.A. Methods for speciation of metals in soils: a review. Journal of Environmental Quality 2005; 34: 1707-1745.

[42] Kaasalainen M., Yli-Halla M. Use of sequential extraction to assess metal partitioning in soils. Environmental Pollution 2003; 126: 225-233.

[43] Indeka L., Karczun Z. Accumulation of selected heavy metals in soils along busy traffic routes. Ecology and Technology 1999; 6: 174-180.

[44] Antonkiewicz J., Macuda J. Levels of heavy metals and hydrocarbons in grounds surrounding some petrol stations in Kraków. Acta Scientiarum Polonorum, Formatio Circumiestus 2005; 4 (2): 31-36. 
[45] Voegborlo R.B., Chirgawi M.B. Heavy metals accumulation in roadside soil and vegetation along major highway in Libiya. Journal of Science and Technology 2007; 27: $1-12$.

[46] Arslan H., Gizir A.M. Heavy-metal content of roadside in Mesin, Turkey. Fresenius Environmental Bulletin 2006; 15: 15-20.

[47] Atafar Z., Mesdaghinia A., Nouri J., Homaee M., Yunesian M., Ahmadimoghaddam M., Mahvi A.H. Effect of fertilizer application on soil heavy metal concentration. Environmental Monitoring Assessment 2010; 160: 83-89.

[48] Basta N.T., Ryan J.A., Chaney R.L. Trace element chemistry in residual-treated soil: key concepts and metal bioavailability. Journal of Environmental Quality 2005; 34: 49-63.

[49] Alloway B.J. Soil processes and the behavior of metals., New York: Wiley; 1995.

[50] Kabata-Pendias A., Pendias H. Biogeochemistry of trace elements. Warsaw: PWN Scientific Publishing House; 1999.

[51] Du Plessis K.R., Botha A., Joubert L., bester R., Conradie W.J., Wolfaardt G.M. Response of the microbial community to copper oxychloride in acidic sandy loam soil. Journal of Applied Microbiology 2005; 98: 901-909.

[52] Wuana R.A., Okieimen F.E. Heavy metals in contaminated soils: a review of sources, chemistry, risks and best available strategies for remediation. ISRN Ecology 2011. doi:10.5402/2011/402647.

[53] De Vries W.R., Römkens P.F.A.M., Van Leeuwen T., Bronswijk J.J.B. Heavy metals. In: Haygarth P.M., Jarvis S.C. (eds.) Agriculture, hydrology and water quality. Nosworthy Way: CABI ; 2002. p. 107-132.

[54] Barcan V. Leaching of nickel and copper from soil contaminated by metallurgical dust. Environment International 2002; 28: 63-68.

[55] Colmer A.R., Hinkel M.E. The role of microorganisms in acid mine drainage: a preliminary report. Science 1947; 106: 253-256.

[56] Lone M.I., He Z., Stoffella P.J., Yang X.. Phytoremediation of heavy metal polluted soils and water: progresses and perspectives. Journal of Zhejiang University Science B (Biomedicine \& Biotechnology) 2008: 9: 210-220

[57] Weinberg E.D. Roles of trace metals in transcriptional control of microbial secondary metabolism. Biology of Metals 1990; 2: 191-196.

[58] Abbas A.S., Edwards C. Effects of metals on Streptomyces coelicolor growth and actinorhodin production. Applied Environmental Microbiology 1990; 56: 675-680.

[59] Bruins M.R., Kapil S., Oehme F.W. Microbial resistance to metals in the environment. Ecotoxicology and Environmental Safety 2000; 45: 198-207. 
[60] Tyler G. Heavy metal pollution and soil enzymatic activity. Plant and Soil 1974; 41: 303-311.

[61] Rajapaksha R.M.C.P. Tabor-Kapłon M.A., Bååth E. Metal toxicity affects fungal and bacterial activities in soil differently. Applied and Environmental Microbiology 2004; 70: $2966-2973$

[62] Bong C.W., Malfatti f., Azam F., Obayashi Y., Suzuki S. The effect of zinc exposure on the bacteria abundance and proteolytic activity in seawater. In: Hamamura N., Suzuki S., Mendo S., Barroso C.M., Iwata H., Tanabe S. (eds.) Interdisciplinary Studies on Environmental Chemistry - Biological Responses to Contaminants. Tokyo: Terrapub; 2010. p. 57-63.

[63] Sobolev D., Begonia M.F.T. Effects of heavy metal contamination upon soil microbes: lead-induced changes in general and denitrifying microbial communities as evidenced by molecular markers. International Journal of Environmental Research and Public Health 2008; 5: 450-456.

[64] Doelman P. Resistance of soil microbial communities to heavy metals. In: Jensen V., Kioller A., Sorensen C.H. (eds.) Microbial communities in soil. London: Elsevier Applied Science Publishers; 1986. p. 369-384.

[65] Juwarkar A.A., Nair A., Dubey K.V., Singh S.K., Devotta S. Biosurfactant technology for remediation of cadmium and lead contaminated soils. Chemosphere 2007; 68: 1996-2002

[66] Lenart A., Wolny-Koładka K. The effect of heavy metal concentration and soil pH on the abundance of selected microbial groups within ArcelorMittal Poland steelworks in Cracow. Bulletin of Environmental Contamination and Toxicology 2013; 90: 85-90

[67] Wyszkowska J., Kucharski J., Borowik A., Boros E. Response of bacteria to soil contamination with heavy metals. Journal of Elementology 2008; 13: 443-453.

[68] Piotrowska-Seget Z., Cycoń M., Kozdrój J. Metal-tolerant bacteria occurring in heavily polluted soil and mine spoil. Applied Soil Ecology 2005; 28: 237-246.

[69] Sprocati A.R., Alisi C., Segre L., Tasso F., Galletti M., Cremisini C. Investigating heavy metal resistance, bioaccumulation and metabolic profile of a metallophile microbial consortium native to abandoned mine. Science of the Total Environment $2006 ; 366 ; 649-658$.

[70] Nies D.H. Efflux-mediated heavy metal resistance in prokaryotes. FEMS Microbiology Reviews 2003; 27: 313-339.

[71] Fogarty R.V, Tobin J.M. Fungal melanins and their interactions with metals. Enzyme and Microbial Technology 1996; 19: 311-317. 
[72] Gadd G.M. Fungal production of citric and oxalic acid: importance in metal speciation, physiology and biogeochemical processes. Advances in Microbial Physiology 1999; 41: 47-92.

[73] Gonzalez H., Jensen T.E. Nickel sequestering by polyphosphate bodies in Staphylococcus aureus. Microbios 1998; 93: 179-185.

[74] Martin T.A., Ruby M.V. Review of in situ remediation technologies for lead, zinc and cadmium in soil. Remediation 2004; 14: 35-53.

[75] USEPA. Recent developments for in situ treatment of metal contaminated soils. Tech. Rep. EPA-542-R-97-004, Washington DC: USEPA; 1997. http://www.clu-in.org/download/remed/metals2.pdf (accessed 15 June 2013).

[76] Evanko C.R., Dzombak D.A. Remediation of metals-contaminated soils and groundwater. Technology Evaluation Report. Pittsburgh: Ground-Water Remediation Technologies Analysis Center; 1997.

[77] Salt D.E., Smith R.D., Raskin I. Phytoremediation. Annual Reviews in Plant Physiology \& Plant Molecular Biology 1998; 49: 643-668.

[78] Raskin I., Smith R.D., Salt D.E. Using plant seedlings to remove heavy metals from water. Plant Physiology 1997; 111: 552-552.

[79] Cunningham S.D., Ow D.W. Promises and prospects of phytoremediation. Plant Physiology 1996; 110: 715-719.

[80] Jing Y., He Z., Yang X. Role of soil rhizobacteria in phytoremediation of heavy metal contaminated soils. Journal of Zhejiang University Science B (Biomedicine \& Biotechnology) 2007; 8: 192-207.

[81] Ebbs S.D., Lasat M.M., Brady D.J., Cornish J., Gordon R., Kochian I.V. Phytoextraction of cadmium and zinc from a contaminated soil. Journal of Environmental Quality $1997 ; 26: 1424-1430$.

[82] Jadia C.D., Fulekar M.H. Phytoremediation of heavy metals: recent techniques. African Journal of Biotechnology 2009; 8: 921-928.

[83] Garbisu C, Alkorta I. Phytoextraction: A cost effective plant-based technology for the removal of metals from the environment. Bioresource Technology 2001; 77: 229-236.

[84] Ajaz Haja Mohideen R., Thirumalai Arasu V., Narayanan K.R., Zahir Hussain M.I. Bioremediation of heavy metal contaminated soil by the Exigobacterium and accumulation of $\mathrm{Cd}, \mathrm{Ni}, \mathrm{Zn}$ and $\mathrm{Cu}$ from soil environment. International Jornal of Biological Technology 2010; 1: 94-101.

[85] Smith S.E., Read D.J. Mycorrhizal symbiosis. San Diego: Academic Press Inc.; 1997. 
[86] Rohwerder T., Gehrke T., Kinzler K., Sand W. Bioleaching review part A: Progress in bioleaching: fundamentals and mechanisms of bacterial metal sulfide oxidation. Applied Microbiology and Biotechnology 2003; 63: 239-248.

[87] Means J.L., Hinchee R.E. Emerging technology for bioremediation of metals. Boca Raton: Lewis Publishers; 1994.

[88] Miller H. Biostimulation as a form of bioremediation of soil pollutans. Basic Biotechnology eJournal 2010 http://ejournal.vudat.msu.edu/index.php/mmg445/article/viewArticle/MMG445.4543071/395 (accessed 10 July 2013).

[89] Gentry T.J., Rensing C., Pepper I.L. New approaches for bioaugmentation as a remediation technology. Critical Reviews in Environmental Science and Technology 2004; 34: 447-494.

[90] Volesky B. Biosorption of heavy metals. Florida: CRC Press; 1990.

[91] Das N., Vimala R., Karthika P. Biosorption of heavy metals - an overview. Indian Journal of Biotechnology 2008; 7: 159-169.

[92] Horikoshi T., Nakajima A., Sakaguchi T. Studies on the accumulation of heavy metal elements in biological systems: accumulation of uranium by microorganisms. European Journal of Applied Microbiology and Biotechnology 1981; 12: 90-96.

[93] Ridley W.P. Dizikes L.J., Wood J.M. Biomethylation of toxic elements in environment. Science 1977; 197: 329-332.

[94] Gadd G.M. Metals, minerals and microbes: geomicrobiology and bioremediation. Microbiology 2009; 156: 609-643.

[95] Gremion F., Chatzinotas A., Kaufmann K., Sigler W.V., Harms H. Impacts of heavy metal contamination and phytoremediation on a microbial community during a twelve-month microcosm experiment. FEMS Microbiology Ecology 2004; 48: 273-283. 
